\title{
FOURIER TRANSFORM INFRARED SPECTROSCOPY AND THERMAL ANALYSES OF KAOLINITIC CLAYS FROM SOUTH AFRICA AND CAMEROON
}

\author{
Makia DIKO $^{1)}$ *, Georges EKOSSE ${ }^{2)}$ and Jason OGOLA ${ }^{3)}$ \\ 1) Geology Division, University of Limpopo, Sovenga, P/B X1106 Limpopo Province, 0727 South Africa \\ 2) Directorate of Research and Innovation, University of Venda, \\ P/B X5050 Limpopo Province, 0950 South Africa \\ 3) Department of Mining and Environmental Geology, University of Venda, \\ P/B X5050 Limpopo Province, 0950 South Africa \\ *Corresponding author's e-mail: dikom73@gmail.com
}

\section{ARTICLE INFO}

\section{Article history}

Received 31 August 2015

Accepted 11 November 2015

Available online 12 December 2015

\section{Keywords:}

Kaolin

Thermal stability

Calcination

Structural order

Industrial application

\section{ABSTRACT}

In this study, Fourier transform infrared (FTIR) spectroscopy, differential scanning calorimetry (DSC) and thermogravimetry (TGA) are used as complementary techniques to investigate structural order and phase transformation associated with thermal decomposition of selected kaolins from South Africa and Cameroon. The samples exhibit poorly resolved, weak intensity $\mathrm{OH}$ stretching and bending vibrations of structural water, characteristic kaolinite dehydroxylation temperatures $\left(500-560{ }^{\circ} \mathrm{C}\right)$, low to high mass loss (6.5 to $\left.19.4 \%\right)$ and asymmetrical DSC curves. The results infer poor to partially ordered structures associated with significant quartz and iron oxide contamination. Compared against other commercial kaolins, the studied samples show moderate to good potentials for use in structural ceramics and refractories.

\section{INTRODUCTION}

Kaolin $\left[\mathrm{Al}_{2} \mathrm{Si}_{2} \mathrm{O}_{5}(\mathrm{OH})_{4}\right]$ is a common phyllosilicate mineral, widely employed as raw material in ceramics, paper filling and coating, refractory, fiberglass, cement, rubber and plastics, paint, catalyst, pharmaceutics and agriculture (Ekosse, 2010; Diko et al., 2011). The minerals of the kaolin group comprises kaolinite, dickite, nacrite, and halloysite with kaolinite being the most common (Murray, 2007). Structurally they consist of the so-called 1:1 layers of combined silicate sheets $\left(\mathrm{Si}_{2} \mathrm{O}_{5}\right)$ bonded to aluminium oxide/hydroxide $\left[\mathrm{Al}_{2}(\mathrm{OH})_{4}\right]$ layers, which are continuous in the a- and $\mathrm{b}$-axis directions and are stacked one above the other in the c-axis direction. Generally, the differences in kaolin minerals are related to the number of unit layers and manner in which they are stacked above each other (Murray, 2007; Vaculíková et al., 2011).

South Africa and Cameroon are two countries from Southern and West Africa respectively with significantly rich kaolin potential (Ekosse, 2010). As developing economies, the contribution of kaolin resources towards economic growth and sustainability of both nations is of paramount importance, however very few deposits have been sufficiently characterized for industrial purpose (Horn and Strydom, 1998; Njoya et al., 2006; Kamsue et al., 2007; Nkoumbou et al., 2009; Diko and Ekosse, 2012; Diko, 2012; Diko and Ekosse, 2014). Current exploitation of most kaolin deposits or occurrences in South Africa and Cameroon are limited to the manufacture of structural ceramic products such as bricks and roofing tiles. The selected kaolin deposits in this study (i.e. Zebediela and Duthuni kaolins in Limpopo Province, north of South Africa) are currently being exploited for bricks, while those from Cameroon (i.e. Moko and Ediki kaolins situated in the Southwest Region) are yet to be exploited for any industrial purpose. These respective deposits have been geologically, physico-chemically and mineralogically characterised in other studies (Diko and Ekosse, 2012; Diko, 2012; Diko and Ekosse, 2014). Genetically, Zebediela, Moko and Ediki deposits were classified as secondary kaolins, while Duthuni as primary (Diko, 2012). Kaolinite was identified as the predominant kaolin mineral in all four deposits, associated with quartz as major constituent, while mica (illite/muscovite) + k-feldspar (as microcline) \pm goethite \pm hematite \pm anatase \pm rutile \pm ilmenite occurred in minor to trace quantities Ekosse, 2014). The aforementioned mineralogical data was obtained through X-Ray diffraction analysis (XRD). Powder XRD for bulk samples were carried out using a Philips PW 1710 XRD unit operated at $40 \mathrm{Kv}$ and $30 \mathrm{~mA}$ with a $\mathrm{Cu}-\mathrm{Ka}$ radiation. The samples were mounted on sample holders with little pressure, using a blade to minimize preferred orientation of the kaolinite particles and scanned scanned for from $3^{\circ} 2 \theta$ to $60^{\circ} 2 \theta$ at a counting time of one second. A graphite monochromator with a PW 1877 Automated Power Diffraction, X'PERT Data Collector soft-ware package was employed qualitative identification of the minerals Diko and Ekosse (2012). Diko (2012) further observed that end products from the studied South African deposits are often characterized by defects such as warping, cracking, (Diko and Ekosse, 2012; Diko, 2012; Diko and 
exploding and peeling during firing which tends to impact on finished product quality. Therefore, in order to optimally exploit these kaolin resources, there is need for in-depth appraisal of the raw material properties.

Although other factors may account for defects in ceramic ware (e.g. inappropriate thermal treatment or percentage mixture of different proportions of the raw material prior to firing) the aforementioned defects in calcined kaolins may be attributed in part to the mineralogical assemblage, structural order and thermal stability of the raw material. An understanding of the degree of crystallinity, thermal behaviour and reaction dynamics during calcination are vital in characterizing kaolin for optimal exploitation (Madejová, 2003; Ekosse and Mulaba, 2008; Vaculíková et al., 2011). In this study, Fourier transform infrared (FTIR) spectroscopy, differential scanning calorimetry (DSC) and thermogravimetry (TGA) are used as complementary techniques to investigate structural order and phase transformation associated with thermal decomposition of the selected kaolins from South Africa and Cameroon in order to appraise their industrial suitability. In order to ascertain kaolinite structural order based on FTIR spectroscopy, Vaculikova et al (2011) recommended two approaches: (1) an empirical approach based on the resolution and relative intensities of $\mathrm{OH}$ stretching and bending vibrations of structural water in kaolinite, and (2) a numerical approach based on crystallinity indices (CI) calculated from the intensities of selected vibrational modes of structural $\mathrm{OH}$ bands. However in this study, only preliminary findings based on the empirical approach are reported. A more detailed study on kaolinite structural order involving comparison of the numerical approach with kaolinite CI (i.e. Hinkcley and Stoch Indices) calculated from XRD diffractograms is still on-going. In addition, thermal behaviour of the studied kaolins are compared against other kaolins with similar mineralogical assemblage and exploited for structural ceramics and refractories (e.g. Makoro and Kgwakwe kaolins, Botswana; Mayououm kaolin, Cameroon; and Mavaiela kaolins, Angola). It is anticipated that findings from this study will contribute towards improvement in end-product quality for the South African kaolinitic clays and give impetus for development of a ceramic plant in Southwest Region, Cameroon.

\section{MATERIAL AND METHODS \\ 2.1. SAMPLES}

A total of four representative bulk kaolin samples from South Africa (denoted ZEB 1 and ZEB 2 from Zebediela and DUT 1 and DUT 2 from Duthuni) and four from Cameroon (denoted MK 1 and MK 2 from Moko, and ED 1 and ED 2 from Ediki) were obtained for FTIR, DSC and TGA analyses. Representativity was ensured by collecting the samples from two main heterogeneous kaolin bearing layers within the respective excavation pits.
Heterogeneity between layers was defined by differences in colour, texture and mineralogy (Diko, 2012). However, in some instances the main difference was texturally driven, as in Ediki kaolin where two facies type; sand-rich and sand-poor kaolin have been identified (Diko and Ekosse, 2012). Within each distinct kaolin-bearing layer across all four deposits studied, four sub-samples were collected at variable intervals and mixed into a single homogenous sample.

\subsection{EXPERIMENTAL}

The IR spectra for bulk kaolin were acquired using a Perkin Elmer System 2000 FTIR spectrophotometer at a resolution of $4 \mathrm{~cm}^{-1}$. About $5 \mathrm{~g}$ of dried powdered samples were homogenized in spectrophotometric grade $\mathrm{KBr}$ in an agate mortar and pressed to $3 \mathrm{~mm}$ pellets with a hand press (Ekosse and Mulaba, 2008). In order not to distort the crystallinity of kaolinite in the samples, the mixing was set to 3 min allowing for minimal grinding as suggested by Tan (1996). Peaks were reported based on percentage transmittance to given wavelengths. Thermal analysis was conducted with a TA instrument SDT Q600 TGA-DSC analyser. Calcined $\mathrm{Al}_{2} \mathrm{O}_{3}$ served as the insert standard, while measurements were performed with $20 \mathrm{mg}$ of samples, heated in air at $10{ }^{\circ} \mathrm{C} / \mathrm{min}$, from $25^{\circ} \mathrm{C}$ to $1100{ }^{\circ} \mathrm{C}$ as discussed in Njoya et al. (2006).

\section{RESULTS AND DISCUSSION 3.1. FTIR SPECTROSCOPY}

The structural order of kaolinites can be detected by differences in position and relative intensity of $\mathrm{OH}$ stretching and bending bands in IR spectrum (Madejová, 2003). The OH bands in kaolin typically display four sharp stretching bands between 3600 and $3700 \mathrm{~cm}^{-1}$ namely; 3697, 3670, 3652/50 and $3620 \mathrm{~cm}^{-1}$ (Ekosse and Mulaba, 2008; Ekosse, 2008; Saikia and Parthasarathy, 2010; Kiros et al., 2013; Djomgoue and Njopwouo, 2013). The strong band at $3697 \mathrm{~cm}^{-1}$ arises from surface hydroxyls and produces an in-phase vibration perpendicular to the 1:1 layers (Ece et al., 2003). The two bands at $3670 \mathrm{~cm}^{-1}$ and $3652 \mathrm{~cm}^{-1}$ arise from stretching vibrations that are sub-parallel to the $1: 1$ layers whereas the low frequency $3620 \mathrm{~cm}^{-1}$ is assigned to the fourth $\mathrm{OH}$ inner group. On the basis of resolution and relative intensities of the bands in the $\mathrm{OH}$ stretching and bending regions, Vaculíková et al. (2011) proposed the following classification schemes for kaolinite structural order:

- $\quad$ Ordered; if the $\mathrm{OH}$ stretching and bending bands are clearly resolved.

- Partially ordered; if the individual $\mathrm{OH}$ bands at $3670 \mathrm{~cm}^{-1}, 3650 \mathrm{~cm}^{-1}$ and $938 \mathrm{~cm}^{-1}$ had low intensities but could be identified.

- Poorly ordered; if only one band near $3660 \mathrm{~cm}^{-1}$ or inflexions near $3670 \mathrm{~cm}^{-1}, 3650 \mathrm{~cm}^{-1}$ and $938 \mathrm{~cm}^{-1}$ were observed in the spectra. 
Table 1 Assignments and infrared band positions of selected kaolin samples from South Africa, Cameroon and theoretical kaolinite.

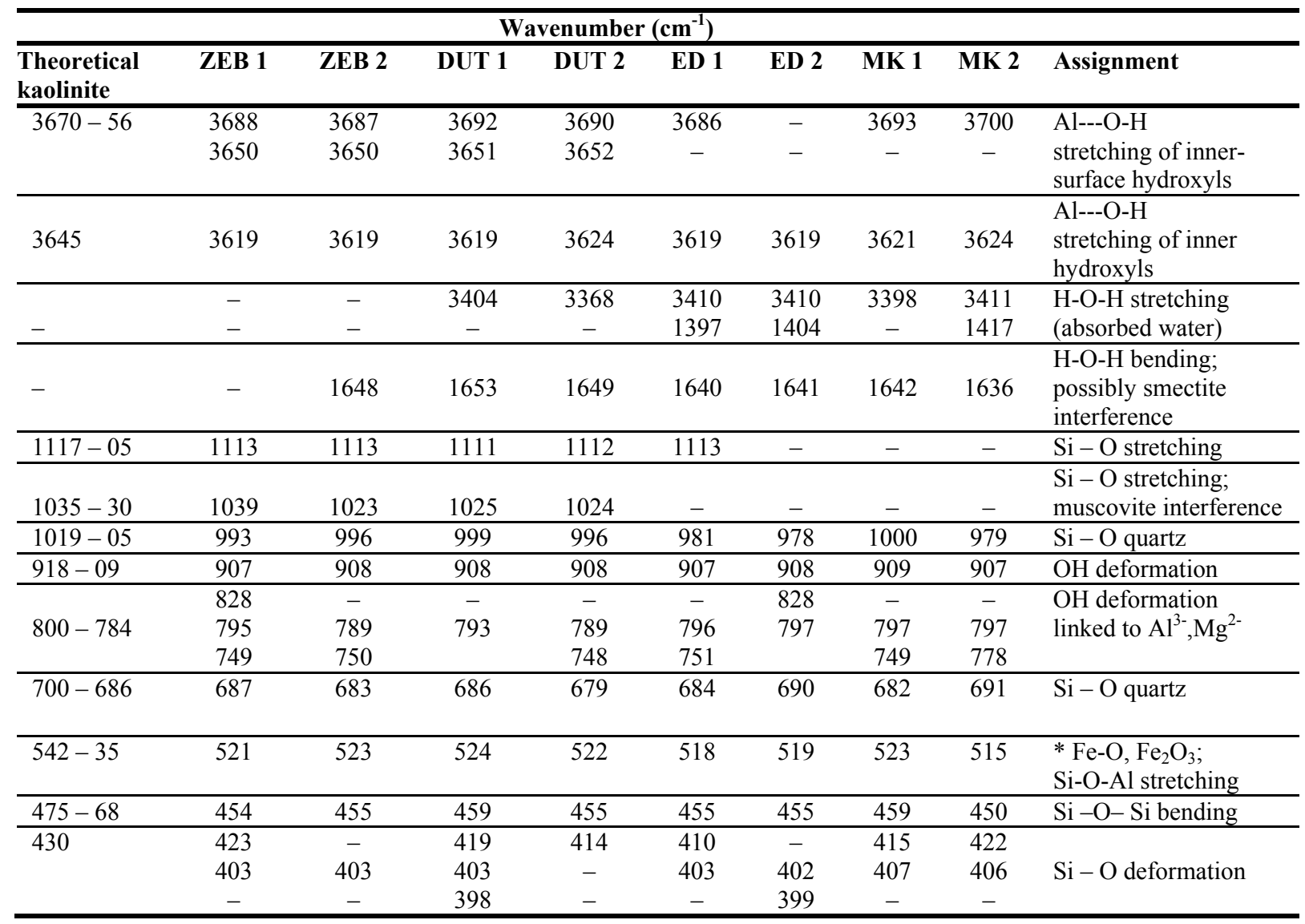

Values for theoretical kaolinite (Vaculíková et al., 2011); * Fe-O, $\mathrm{Fe}_{2} \mathrm{O}_{3}$ not present in theoretical kaolinite;

$(-)$, very weak intensity or not detected.

The positions and assignments of the transmittance bands of representative samples from South Africa and Cameroon compared against that of theoretical kaolinite is summarized in Table 1. Three characteristic peaks at $3688 / 3687 \mathrm{~cm}^{-1}$, $3651 / 3652^{\circ} \mathrm{C}^{\circ} \mathrm{C} \mathrm{cm}^{\circ} \mathrm{C}^{-1}$ and $3690 / 3692 \mathrm{~cm}^{-1}$ were observed in ZEB 1, ZEB 2, DUT 1 and DUT 2 (Fig. 1 $(\mathrm{a}-\mathrm{d})$, a weak doublet between $3620 \mathrm{~cm}^{-1}$ and $3700 \mathrm{~cm}^{-1}$ was present in MK 1 and MK 2 (Fig. 2 $\mathrm{a}$ and $\mathrm{b}$ ) whereas only a single clearly resolved 3619 $\mathrm{cm}^{-1}$ peak with very weak inflexion at $3686 \mathrm{~cm}^{-1}$ characterized ED 1 and ED 4 (Fig. 2c and d). Low frequency peaks at $3620 \mathrm{~cm}^{-1}$ and $3619 \mathrm{~cm}^{-1}$ were prominent in all the samples. Single broad bands at $3650 / 3651 \mathrm{~cm}^{-1}$, were observed in samples ED 1 and 2, indicative of poor structural order (Saikia and Parthasarathy, 2010; Kiros et al., 2013; Djomgoue and Njopwouo, 2013). Muscovite + quartz interference was identified in all the samples whereas iron oxides were prominent in ZEB 2, DUT 1, DUT 2, MK 1 and MK 2 but absent in ED 1 and ED 2. According to Saikia and Parthasarathy (2010) broad H-O-H bands at $3450 \mathrm{~cm}^{-1}$ and weak peaks at $1633 \mathrm{~cm}^{-1}$ in DUT 6 , DUT 13, MK 1, MK 2, ED 1 and ED4 may contribute significantly towards mass loss during calcination. The IR spectrum infers the following increasing structural order; ED $2<$ ED $1<$ MK $2<$ MK $1<$ ZEB $2<$ ZEB 1, with ED 2 having the least and ZEB 1 the most.

\subsection{THERMAL ANALYSIS}

The DSC curves show endothermic and exothermic reactions during calcination, such as desorption of surface water $\left(\mathrm{H}_{2} \mathrm{O}\right)$, dehydroxylation (structural $\mathrm{OH}$-groups) and the transformation to mullite and cristobalite, with resultant temperature effects of dehydroxylation and polymorphic transformation strongly dependent on kaolinite structural order (Ece et al., 2003; Ekosse, 2008).

Kaolin group minerals are characterised by two major endothermic peaks and one exothermic peak. The exothermic peak corresponds to the destruction of the 1:1 kaolinite structure and is typically observed between $943{ }^{\circ} \mathrm{C}$ and $968{ }^{\circ} \mathrm{C}$ (Ece et al., 2003; Ekosse, 2008). The dehydroxylation temperature of most kaolinites ranges from $498{ }^{\circ} \mathrm{C}$ to $605{ }^{\circ} \mathrm{C}$, whereas the dehydroxylation of dickite and nacrite occurs at $680^{\circ} \mathrm{C}$. According to Ece et al. (2003) and Saviano et al. (2005) well-ordered kaolinites have broad endothermic peaks at approximately $590{ }^{\circ} \mathrm{C}$ however, Njoya et al. (2006) reported endothermic peaks for well-ordered kaolinites from Mayouom at 520 


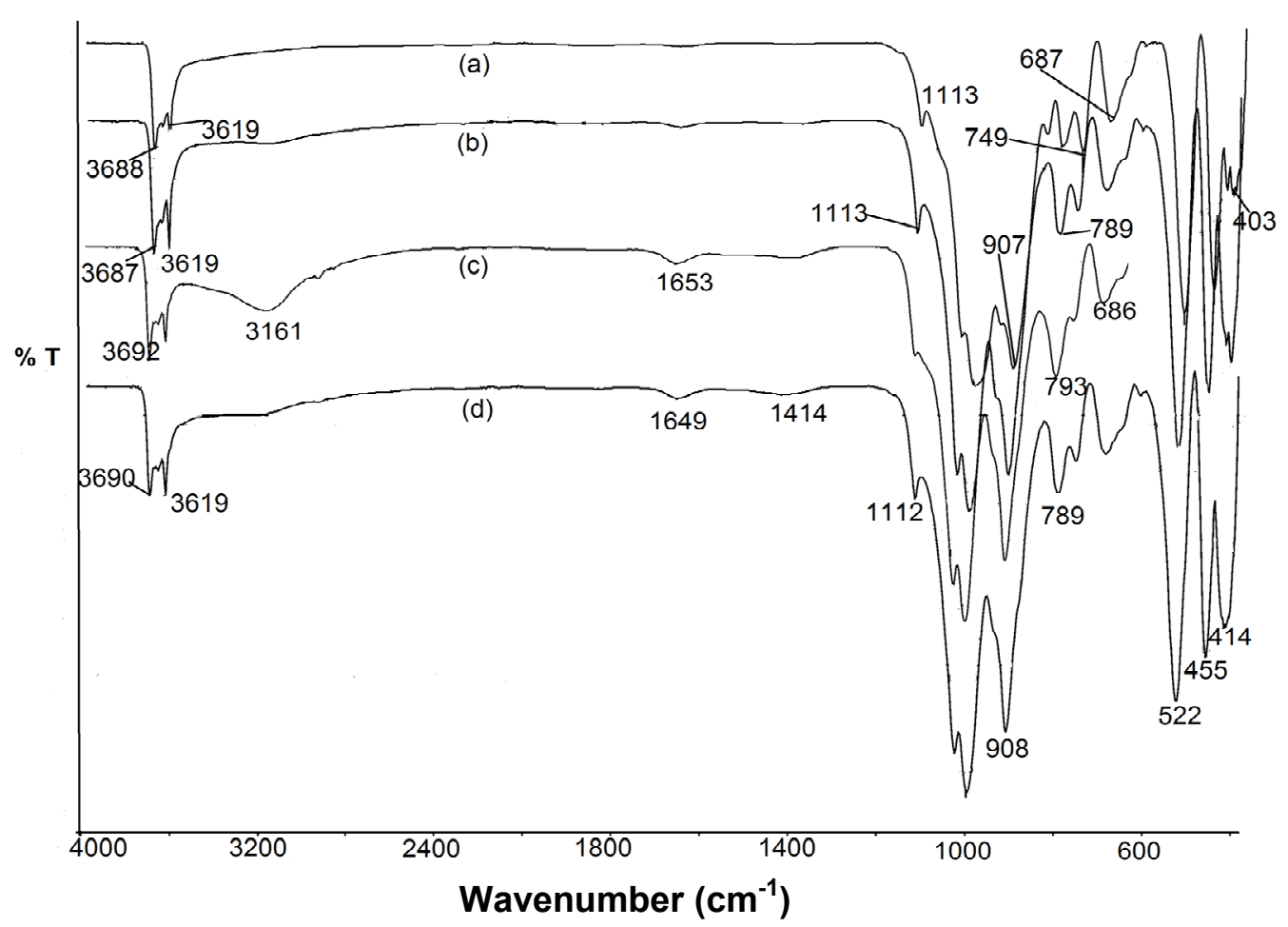

Fig. 1 FTIR spectra of bulk kaolin samples from South Africa: (a) ZEB 1, (b) ZEB 2, (c) DUT 1, (d) DUT 2.

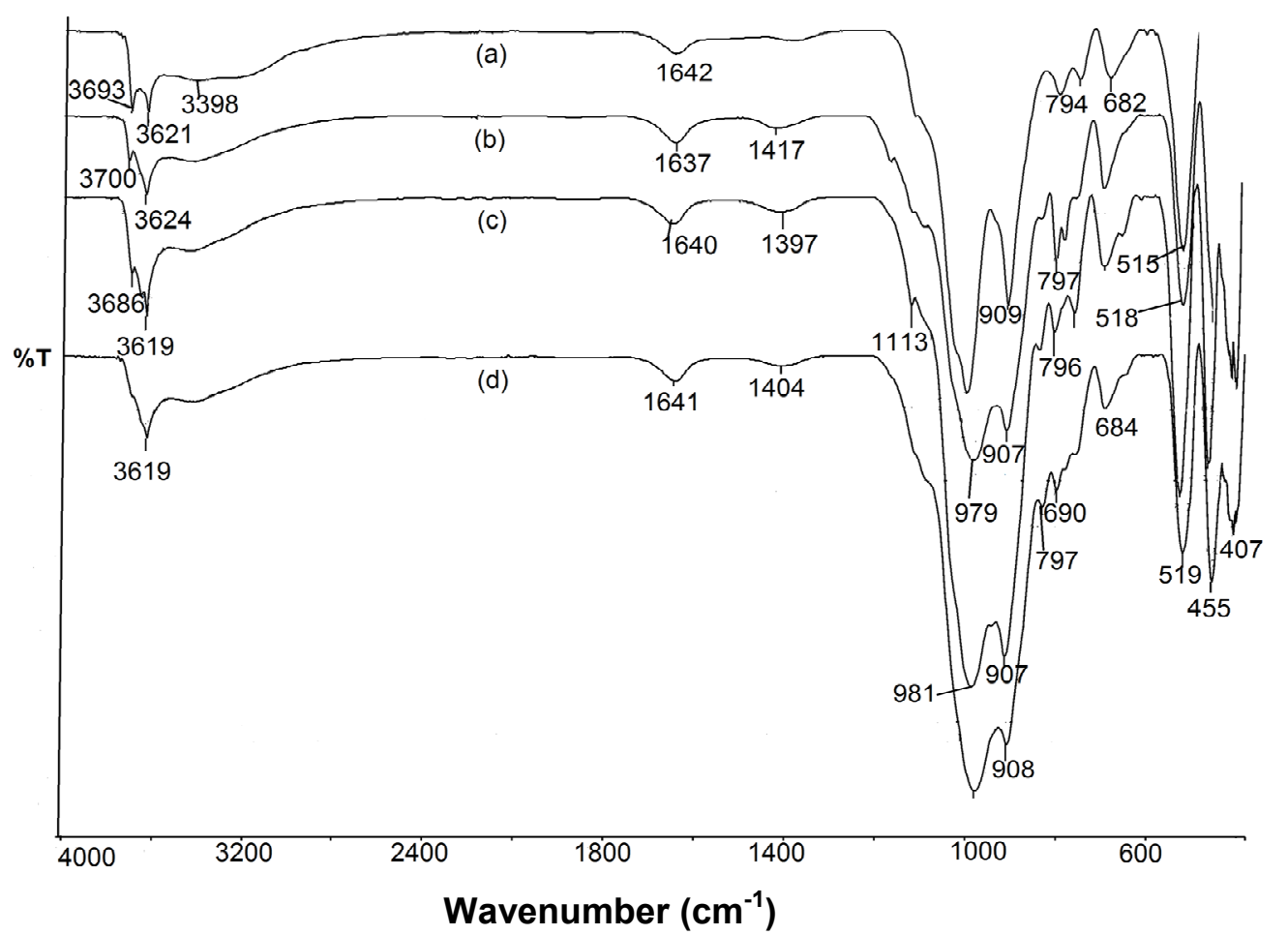

Fig. 2 FTIR spectra of bulk kaolin samples from Cameroon: (a) MK 1, (b) MK 2, (c) ED 1, (d) ED 2.

$522{ }^{\circ} \mathrm{C}$. Conversely, major weight losses during $\mathrm{TG}$ experiments are typically observed between 400 and $600{ }^{\circ} \mathrm{C}$ (Saviano et al., 2005).

The DSC - TG curves of DUT 1 and DUT 2, ED 1 and ED 2, and MK 1 and MK 2 were not significantly different hence only one of each has been presented. With the exception of ZEB 1 (Fig. 3), low temperature endothermic peak observed between $85^{\circ} \mathrm{C}$ to $110{ }^{\circ} \mathrm{C}$ was recorded in the rest of the samples (Figs. $4-7$ ). A second endothermic peak observed between $295^{\circ} \mathrm{C}$ and $350{ }^{\circ} \mathrm{C}$ in ZEB 2, DUT 1 and MK 2 (Figs. 4, 5 and 7 respectively) was attributed to dehydroxylation reactions of goethite $(\alpha-\mathrm{FeO} . \mathrm{OH})$ resulting in the formation of hematite as represented by the equation below: 


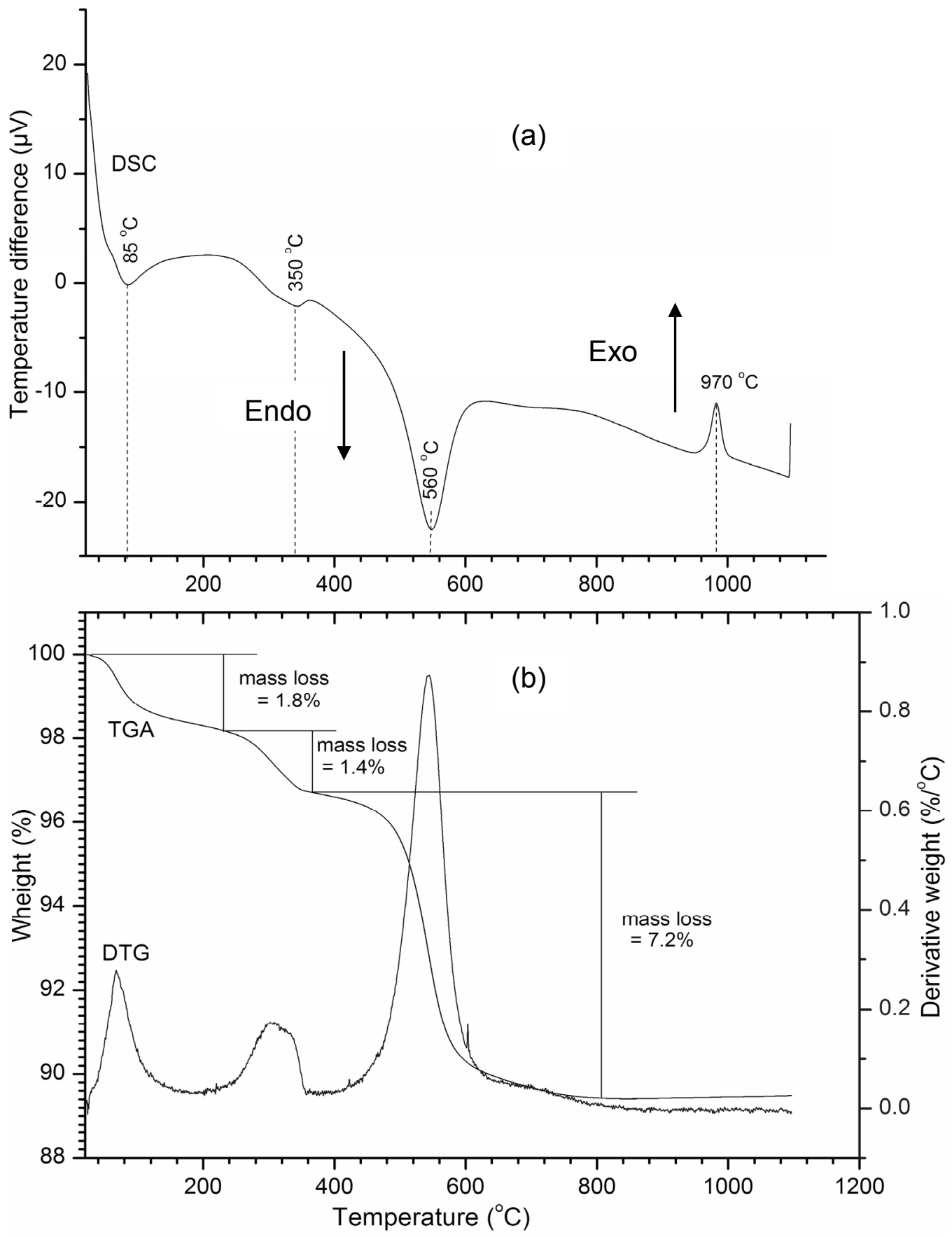

Fig. 3 Thermal analyses of ZEB 1: (a) DSC curve; (b) TGA/DTG curve.

$$
\begin{aligned}
& 2 \alpha-\mathrm{FeO} . \mathrm{OH} \rightarrow \alpha-\mathrm{Fe}_{2} \mathrm{O}_{3}+\mathrm{H}_{2} \mathrm{O} \\
& \text { Goethite hematite }
\end{aligned}
$$

The DSC scans also portrayed samples having endothermic peaks between $500{ }^{\circ} \mathrm{C}$ to $560{ }^{\circ} \mathrm{C}$, corresponding to dehydroxylation and transformation of kaolinite to metakaolinite as indicated below:

$$
\begin{array}{ll}
\mathrm{Al}_{2} \mathrm{Si}_{2} \mathrm{O}_{5}(\mathrm{OH})_{4} & \rightarrow \mathrm{Al}_{2} \mathrm{Si}_{2} \mathrm{O}_{7}+\mathrm{H}_{2} \mathrm{O} \\
\text { Kaolinite } & \text { metakaolinite }
\end{array}
$$

Exothermic temperature peaks between $930{ }^{\circ} \mathrm{C}$ and $1000{ }^{\circ} \mathrm{C}$ were attributed to the temperature range for mullite formation from metakaolinite (Ekosse, 2008) as per the following equation:

$$
\underset{\begin{array}{c}
3 \mathrm{Al}_{2} \mathrm{Si}_{2} \mathrm{O}_{7} \\
\text { Metakaolinite }
\end{array}}{\rightarrow} \quad \begin{gathered}
\mathrm{Al}_{6} \mathrm{Si}_{2} \mathrm{O}_{13} \\
\text { mullite }
\end{gathered}
$$

In addition, differential mass losses ranging from $6.5 \%$ to $19.4 \%$ accompanied the endothermic reactions of the studied kaolins (Figs. 3 - 7). Dehydration reactions involving loss of adsorbed water and destruction of structural $\mathrm{OH}$ during kaolinite dehydroxylation is considered to have accounted for the observed mass losses. The high values reported for DUT 1, DUT 2, MK 1 and MK 2 corroborates with the presence of broad H-O-H bands whereas the comparatively lower mass loss in Ediki samples (Fig. 6) is attributed to minor kaolinite 


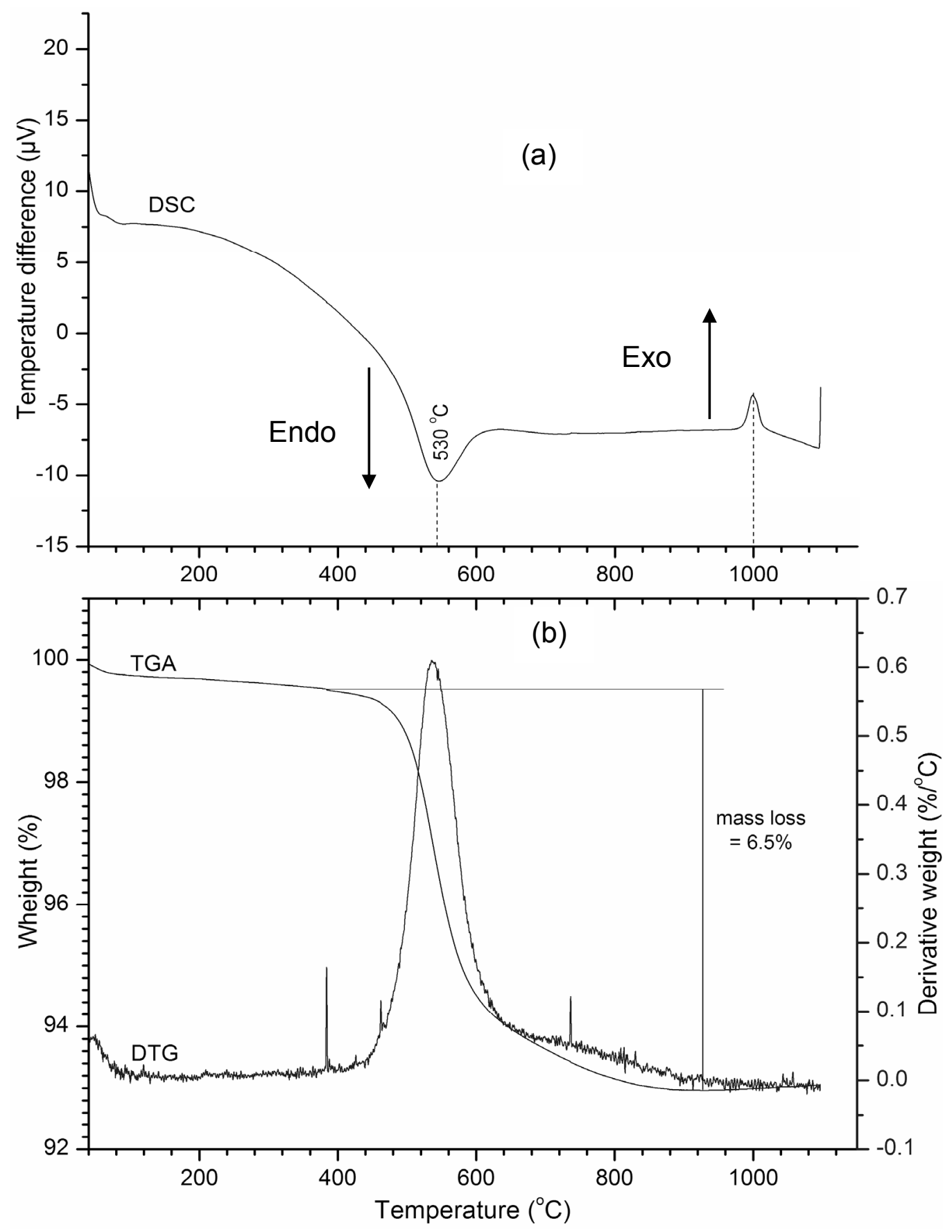

Fig. 4 Thermal analyses of ZEB 2: (a) DSC curve; (b) TGA/DTG curve.

content and weak $\mathrm{H}-\mathrm{O}-\mathrm{H}$ bands. The lack of symmetry displayed by the DSC curves, kaolinite dehydroxylation temperatures $\left(500-650{ }^{\circ} \mathrm{C}\right)$ together with goethite dehydroxylation reactions observed in the studied kaolins, suggests moderate degrees of crystallinity (Saviano et al., 2005). According to Ekosse (2008), oxides and other associated clay minerals (e.g mica and smectite) may equally have influenced the reaction dynamics.

In order to further assess the industrial suitability potentials, thermal stability and reaction dynamics of the studied kaolins were compared against those of selected kaolins exploited for a range of industrial applications (Table 2). The endothermic peak temperatures and main reactions of the studied kaolins were similar to those reported for Makoro and Kgwakwe kaolins (Botswana) widely employed in the manufacture of ceramics (Ekosse, 2000; 2001). In contrast, exothermic peak temperatures of the studied kaolins were lower than those for Makoro and Kgwakgwe. Compared to Mayouom kaolins, utilised for white firing ceramics and refractories (Njoya et al., 2006; Nkoumbou et al., 2009), exothermic temperatures for MK 1 and 2 were much lower whereas the rest of the samples recorded comparatively higher values (Table 2). With the exception of MK 1 and MK 2, exothermic temperatures of the studied samples were close to that of Mavaiela kaolins, used for bricks, tile and paper (Saviano et al., 2005; Ekosse, 2010). Apart from MK 

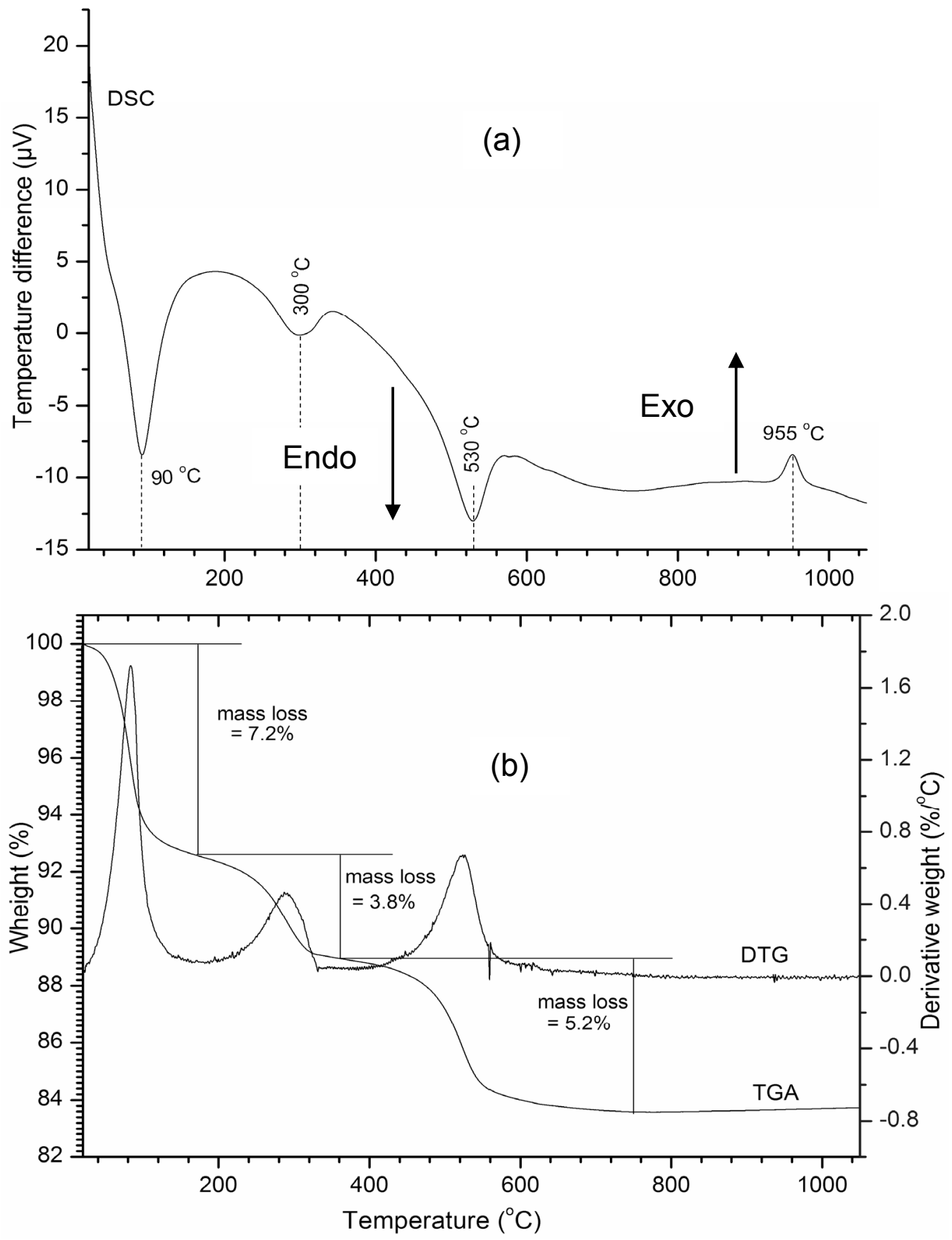

Fig. 5 Thermal analyses of DUT 1: (a) DSC curve; (b) TGA/DTG curve.

1 and MK 2 with higher mass loss (14.4 - 19.4 wt. $\%$ ), values for the other samples were consistent with those reported for Mayouom, Mavaiela, Makoro and Kgwakgwe kaolins (Table 2).

\section{CONCLUSION}

Selected kaolins from South Africa (ZEB 1, ZEB 2, DUT 1 and DUT 2) and Cameroon (MK 1, MK 2, ED 1 and ED 2) have been characterised by FTIR and simultaneous DSC - TG analyses in order to elucidate on their structural order and thermal stability. Kaolinite order was determined based on empirical analysis of the resolution and relative intensity of the $\mathrm{OH}$ stretching and bending vibrations of structural water. In terms of kaolinite finger prints, three characteristic peaks at $3688 / 3687 \mathrm{~cm}^{-1}$, $3651 / 3652 \mathrm{~cm}^{-1}$ and $3690 / 3692 \mathrm{~cm}^{-1}$ were observed in the South African clays. A weak doublet between $3620 \mathrm{~cm}^{-1}$ and $3700 \mathrm{~cm}^{-1}$ was present in MK 1 and MK 2 whereas only a single clearly resolved peak at $3619 \mathrm{~cm}^{-1}$, single broad band at $3650 / 3651 \mathrm{~cm}^{-1}$ with very weak inflexion at $3686 \mathrm{~cm}^{-1}$ characterized ED 1 and ED 2. Low frequency peaks at $3620 \mathrm{~cm}^{-1}$ and $3619 \mathrm{~cm}^{-1}$ were prominent in all the samples. Based on changes in relative intensities of $\mathrm{OH}$ stretching and bending vibrations the following kaolinite structural order was inferred; ED $2<$ ED $1<$ MK $2<$ MK $1<$ ZEB $2<$ ZEB 1, with ED 2 having the least order and 

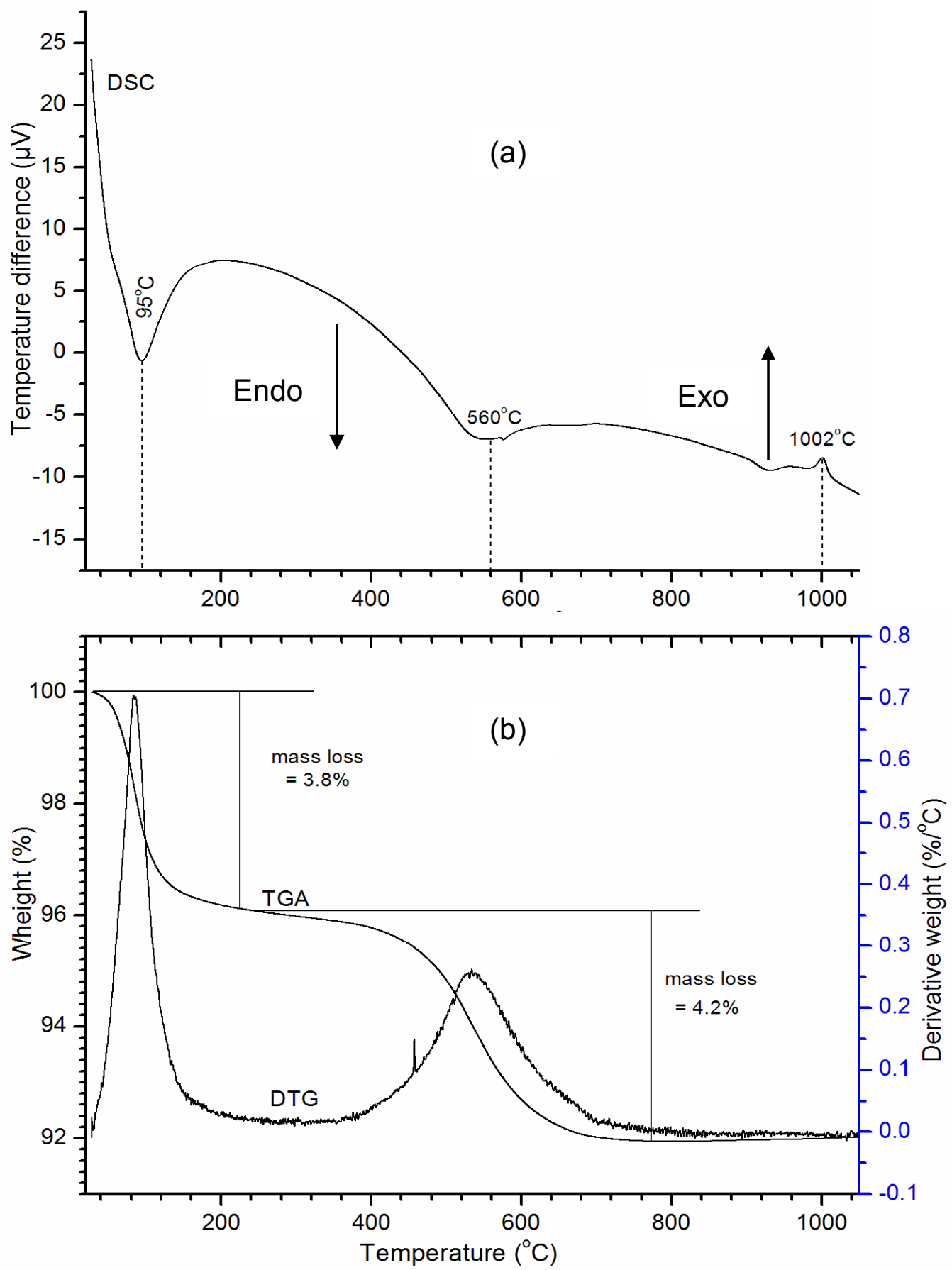

Fig. 6 Thermal analyses of ED 1: (a) DSC curve; (b) TGA/DTG curve.

ZEB 1 the most. In addition to the Al---OH functional group, the IR spectra equally inferred muscovite + quartz interference, and iron oxide enrichment in the samples. The mineralogical phases identified from IR study were found to be consistent with previously reported XRD data.

Thermal behaviour was ascertained from decomposition peak temperatures, mineralogical phase transformations and cumulative mass loss, inferred from the DSC - TG curves. The following endothermic and exothermic reactions were observed; dehydration of adsorbed water $\left(85-110^{\circ} \mathrm{C}\right)$, goethite dehydroxylation $\left(295-350{ }^{\circ} \mathrm{C}\right)$, kaolinite dehydroxylation $\left(500-560{ }^{\circ} \mathrm{C}\right)$, and kaolinite recrystallization $\left(930-1002{ }^{\circ} \mathrm{C}\right)$. In addition, differential mass losses ranging from $6.5 \%$ to $19.4 \%$ were attributed to loss of adsorbed water and destruction of structural $\mathrm{OH}$ during kaolinite dehydroxylation. The characteristic kaolinite dehydroxylation temperatures $\left(500-560{ }^{\circ} \mathrm{C}\right)$, mass loss (6.5 to $19.4 \%$ ) coupled with a lack of observable symmetry from the DSC curves displayed by the studied kaolins corroborates with suggested poor to partially ordered kaolinite structures. Based on comparison of thermal behaviour against other commercial kaolins, the samples show moderate to good potentials for use in structural ceramics and refractories. However, additional technological appraisal is recommended in order to substantiate current findings. 

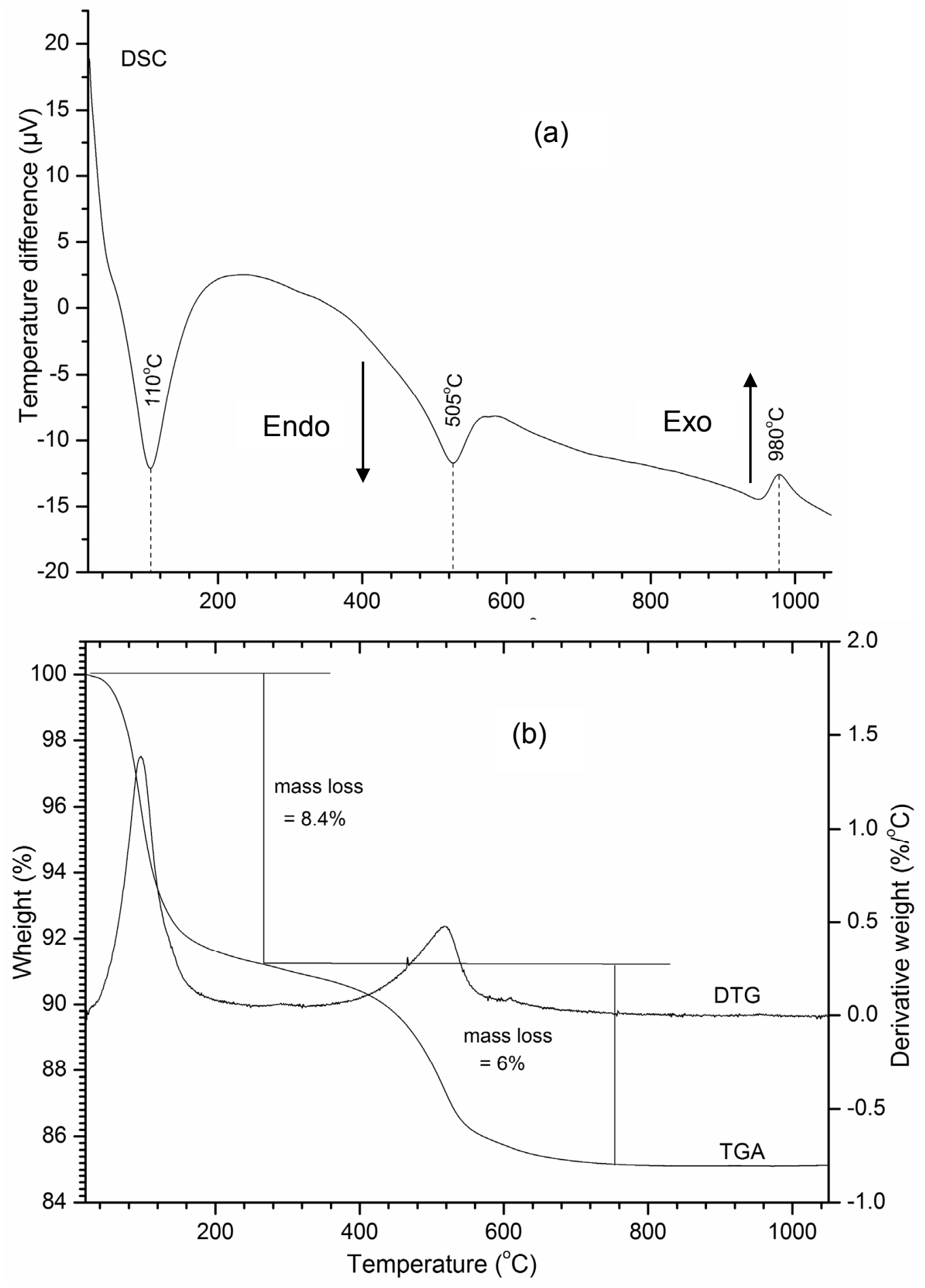

Fig. 7 Thermal analyses of MK 2: (a) DSC curve; (b) TGA/DTG curve.

\section{ACKNOWLEDGEMENTS}

Funding from UNESCO/IUGS/IGCP 545 Project on Clays and Clay Minerals in Africa is acknowledged.

\section{REFERENCES}

Diko, M.L. and Ekosse, G.E.: 2012, Physico-chemical and mineralogical considerations of Ediki sandstonehosted kaolin occurrence, South West Cameroon. International Journal of Physical Science, 7, No. 3, 501-507. DOI: 10.5897/IJPS11.1506
Diko, M.L. and Ekosse, G.E.: 2014, Soil ingestion and associated health implications: a physicochemical and mineralogical appraisal of geophagic soils from Moko, Cameroon. Studies on Ethno-medicine, 8, No. 1, 8388.

Diko, M.L., Ekosse, G.E., Ayonghe. S.N. and Ntasin, E.: 2011, Physical characterization of clayey materials from Tertiary volcanic cones in Limbe (Cameroon) for ceramic applications. Applied Clay Science, No. 51, 380-384. DOI:10.1016/j.clay.2010.11.034

Diko, M.L.: 2012, Genesis and ceramic applications of selected kaolin occurrences from Limpopo Province, 
Table 2 DSC-DTG endothermic and exothermic peak temperatures and main reactions of representative samples from South Africa and Cameroon compared against Mayouom, Mavaiela, Makoro and Kgwakgwe kaolins.

\begin{tabular}{|c|c|c|c|c|c|c|c|c|c|c|c|c|}
\hline $\overrightarrow{⿱ 亠 凶}$ & $\stackrel{N}{N}$ & 占 & 稜 & $\overrightarrow{0}$ & $\hat{⿵}$ & $\bar{v}$ & $\ddot{z}$ & है & 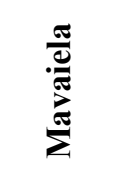 & 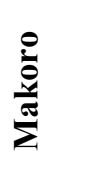 & 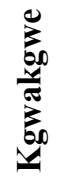 & $\begin{array}{c}\text { Main } \\
\text { reaction }\end{array}$ \\
\hline \multicolumn{13}{|c|}{ Endothermic peaks $\left({ }^{\circ} \mathrm{C}\right)$} \\
\hline- & 85 & 90 & 85 & 95 & 95 & 105 & 110 & - & $100-105$ & - & 120 & $\begin{array}{l}\text { Dehydration of } \\
\text { adsorbed water }\end{array}$ \\
\hline- & 350 & 300 & 295 & - & - & 305 & - & - & - & 350 & - & $\begin{array}{c}\text { Goethite } \\
\text { dehyroxylation }\end{array}$ \\
\hline 530 & 560 & 530 & 535 & 560 & 560 & 500 & 505 & $520-522$ & $550-540$ & 605 & 610 & $\begin{array}{c}\text { Kaolinite } \\
\text { dehydroxylation }\end{array}$ \\
\hline 6.5 & 10.4 & 16.2 & 10.5 & 8 & 9.2 & 19.4 & 14.4 & $12-13$ & - & $12-16$ & $6-13$ & $\begin{array}{c}\text { Mass loss } \\
\text { (Wt. \%) }\end{array}$ \\
\hline \multicolumn{13}{|c|}{ Exothermic peaks $\left({ }^{\circ} \mathrm{C}\right)$} \\
\hline 1000 & 970 & 955 & 945 & 1002 & 930 & 960 & 980 & $980-975$ & 1000 & 1000 & 1020 & $\begin{array}{c}\text { Recrystallization } \\
\text { of kaolinite }\end{array}$ \\
\hline
\end{tabular}

Values for Mayououm, Mavaiela, Makoro and Kgwakgwe obtained from Njoya et al. (2006), Saviano et al (2005); and Ekosse, 2000; 2001 respectively.

South Africa and South West Region, Cameroon. PhD thesis, University of Limpopo, South Africa, $239 \mathrm{pp}$.

Djomgoue, P. and Njopwouo, D.: 2013, FT-IR Spectroscopy applied for surface clays characterization. Journal of Surface Engineered Materials and Advanced Technology, 3, 275-282.

DOI: http://dx.doi.org/10.4236/jsemat.2013.34037

Ece, O.I., Nakagawa, Z. and Schroed, P.: 2003, Alteration of volcanic rocks and genesis of kaolin deposits in the Sile region, Northern Istanbul, Turkey. Clay Mineralogy. Clays and Clay Minerals, 51, No. 6, 675688. DOI: 10.1346/CCMN.2003.0510610

Ekosse, G.E. and Mulaba, A.: 2008, Mineral thermochemistry of bentonite and kaolinite related to their possible application in the ceramic industry. Journal of Applied Sciences 8, No. 22, 4145-4151. DOI: $10.3923 /$ jas.2008.4145.4151

Ekosse, G.E.: 2000, The Makoro kaolin deposit, southeastern Botswana: its genesis and possible industrial applications. Applied Clay Science, 16, 301-320. DOI: 10.1016/S0169-1317(99)00059-9

Ekosse, G.E.: 2001, Provenance of the Kgwakgwe kaolin deposit in southeastern Botswana and its possible utilization. Applied Clay Science, 20, 137-152. DOI:10.1016/S0169-1317(01)00064-3

Ekosse, G.E.: 2008, Thermoanalytical characterization, stable isotope and paleoenvironmental considerations of kaolinite from two genetic sources. Fresenius Environmental Bulletin, 17, No. 1, 29-42.

Ekosse, G.E.: 2010, Kaolin deposits and occurrences in Africa: Geology, mineralogy and utilization. Applied Clay Science, 50, No. 2, 212-236.

DOI:10.1016/j.clay.2010.08.003

Horn, G.F. and Strydom, J.H.: 1998, Clay. In: Wilson M.G. and Anhaeusser C.R., (Eds.): The Mineral Resources of South Africa. Council for Geoscience, 16, 106-135.

Kamsue, E., Leonelli, C., Boccaccini, D. N., Veronesi, P., Miselli, P., Giancarlo, P. and Chinje Melo, U.: 2007, Characterisation of porcelain compositions using two china clays from Cameroon. Ceramics International, 33, 851-857. DOI: 10.5897/IJPS12.714
Kiros, A., Gholap, A. and Gigante, G.E.: 2013, Fourier transform infrared spectroscopic characterization of clay minerals from rocks of Lalibela churches, Ethiopia. International Journal of Physical Sciences, 8, No 3, 109-119. DOI: 10.5897/IJPS12.714

Madejová, J.: 2003, FTIR techniques in clay mineral studies. Vibrational Spectroscopy, 31, 1-10. DOI: 10.1016/S0924-2031(02)00065-6

Murray, H.H.: 2007, Applied clay mineralogy. occurrences, processing and application of kaolins, bentonites, palygorskite-Sepiolite and common clays. Developments in Clay Science, No. 2, 179 pp.

Njoya, A., Nkoumbou, C., Grosbois, C., Njopwouo, D., Njoya, D., Courtin-Nomade, A., Yvon, J. and Martin, F.: 2006, Genesis of Mayouom kaolin deposit (western Cameroon). Applied Clay Science, 32, 125140. DOI: 10.1016/j.clay.2005.11.005.

Nkoumbou, C., Njoya, A., Njoya, D., Grosbois, C., Njopwouo, D., Yvon, J. and Martin, F.: 2009, Kaolin from Mayouom (Western Cameroon): Industrial suitability evaluation. Applied Clay Science, 43, 118124. DOI:10.1016/j.clay.2008.07.019

Saikia, B. and Parthasarathy, G.: 2010, Fourier Transform Infrared Spectroscopic Characterization of kaolinite from Assam and Meghalaya, Northeastern India. Journal of Modern Physics, 1, 206-210. DOI: $10.4236 /$ jmp.2010.14031

Saviano, G., Maurizio, V., Umberto, P. and Emidio, T.L.: 2005, Kaolin deposits from the northern sector of Cunene Anorthosite Complex (Southern Angola). Clays and Clay Minerals, 53, No. 6, 674-685. DOI: $10.1346 / C C M N .2005 .0530613$

Tan, K.H.: 1996, Soil sampling preparation and analysis. Marcel Dekker Inc. New York,

Vaculíková, L., Plevová, E., Vallová, S. and Koutník, I.: 2011, Characterization and differentiation of kaolinites from selected Czech deposits using infrared spectroscopy and differential thermal analysis. Acta Geodyn. Geomater., 8, No. 161, 59-67. 